\title{
Thioltransferase (Glutaredoxin) Mediates Recovery of Motor Neurons from Excitotoxic Mitochondrial Injury
}

\author{
Rajappa S. Kenchappa, ${ }^{1,2}$ Latha Diwakar, ${ }^{1}$ Michael R. Boyd, ${ }^{3}$ and Vijayalakshmi Ravindranath ${ }^{1,2}$ \\ ${ }^{1}$ Department of Neurochemistry, National Institute of Mental Health and Neurosciences, Bangalore 560 029, India, \\ 2National Brain Research Centre, Gurgaon 122001, India, and ${ }^{3}$ Cancer Research Institute, College of Medicine, Mobile, \\ Alabama 36688
}

\begin{abstract}
Mitochondrial dysfunction involving electron transport components is implicated in the pathogenesis of several neurodegenerative disorders and is a critical event in excitotoxicity. Excitatory amino acid L- $\beta-N$-oxalylamino-L-alanine (L-BOAA), causes progressive corticospinal neurodegeneration in humans. In mice, L-BOAA triggers glutathione loss and protein thiol oxidation that disrupts mitochondrial complex I selectively in motor cortex and lumbosacral cord, the regions affected in humans. We examined the factors regulating postinjury recovery of complex I in CNS regions after a single dose of L-BOAA. The expression of thioltransferase (glutaredoxin), a protein disulfide oxidoreductase regulated through AP1 transcription factor was upregulated within 30 min of L-BOAA administration, providing the first evidence for functional regulation of thioltransferase during restoration of mito-
\end{abstract}

chondrial function. Regeneration of complex I activity in motor cortex was concurrent with increase in thioltransferase protein and activity, $1 \mathrm{hr}$ after the excitotoxic insult. Pretreatment with $\alpha$-lipoic acid, a thiol delivery agent that protects motor neurons from L-BOAA-mediated toxicity prevented the upregulation of thioltransferase and AP1 activation, presumably by maintaining thiol homeostasis. Downregulation of thioltransferase using antisense oligonucleotides prevented the recovery of complex I in motor cortex and exacerbated the mitochondrial dysfunction in lumbosacral cord, providing support for the critical role for thioltransferase in maintenance of mitochondrial function in the CNS.

Key words: excitatory amino acid; glutaredoxin; mitochondria; motor neuron disease; glutathione; brain; complex I; oxidative stress
Excitotoxicity plays an important role in the pathogenesis of neurodegenerative disorders (Tapia et al., 1999). Mitochondria are critically involved in excitotoxic injury, accumulating large amounts of calcium and generating reactive oxygen species (Lopachin, 1999). Close association and synergistic interplay exists between excitotoxicity, mitochondrial dysfunction, and neurodegeneration. L- $\beta$ - $N$-Oxalylamino-L-alanine (L-BOAA; synonym, $\beta$ - $N$-oxalyl- $\alpha, \beta$-diaminopropionic acid, $\beta$-ODAP) is a nonprotein amino acid first isolated from the chickling pea obtained from the plant Lathyrus sativus (Rao et al., 1964) grown in drought-prone areas of Africa and Asia. Ingestion of the chickling pea as a staple food leads to a progressive, neurodegenerative disorder, neurolathyrism, a form of motor neuron disease (Selye, 1957) that involves upper motor neurons, degeneration of anterior horn cells, and loss of axons in pyramidal tracts of lumbar spinal cord (Streifler et al., 1977; Cohn and Streifler, 1981). L-BOAA exerts its neurotoxicity through the AMPA subclass of glutamate receptors (Pearson and Nunn, 1981; Ross et al., 1989).

Male mice show selective loss of rotenone-sensitive mitochondrial complex I activity (NADH ubiquinone 1 oxidoreductase) in frontoparietal cortex (location of the motor cortex) and lumbosacral segment of spinal cord after receiving a single dose of L-BOAA, whereas other CNS and non-CNS tissues are unaf-

\footnotetext{
Received April 12, 2002; revised July 19, 2002; accepted July 22, 2002.
}

This work was funded by a grant from the United States-India fund for Cultural, Educational, and Scientific Cooperation. We thank Prof. D. N. Rao and U. T. Sankpal of Indian Institute of Science (Bangalore, India) for help with the gel mobility shift assays and S. N. Hegde for help with the histology experiments.

Correspondence should be addressed to Vijayalakshmi Ravindranath, National Brain Research Centre, SCO 5,6,7, Sector 15 (2), Gurgaon 122001, India. E-mail: vijir@vsnl.com.

Copyright (ㄷ) 2002 Society for Neuroscience $0270-6474 / 02 / 228402-09 \$ 15.00 / 0$ fected. The inhibitory effect of L-BOAA on complex I activity in motor cortex and lumbosacral cord can be reversed in vitro by the disulfide reductant dithiothreitol, indicating that the inhibition occurs through oxidation of critical thiol groups in complex I subunits (Sriram et al., 1998).

During oxidative stress, reduced glutathione (GSH) is oxidized to glutathione disulfide (GSSG) in most non-CNS tissues, cells, and organelles. In contrast, in brain (Shivakumar and Ravindranath, 1992; Shivakumar et al., 1995) and brain mitochondria in particular (Ravindranath and Reed, 1990), oxidative stress results in extensive formation of protein-glutathione mixed disulfides at available cysteine residues. Although glutathionylation of proteins is seen in certain cells of non-neural origin (Schuppe et al., 1992; Rokutan et al., 1994), it is more pronounced in brain, presumably because extrusion of GSSG, as routinely observed in other tissues such as lung and liver, is not always seen in brain (Ravindranath and Reed, 1990; Shivakumar et al., 1995).

Thiol-disulfide oxidoreductases comprise a class of enzyme that is primarily involved in catalysis of thiol-disulfide interchange reactions. This includes thioltransferase (glutaredoxin), thioredoxin, and protein disulfide isomerase (Holmgren, 1989; Wells et al., 1993). Thioltransferase was initially discovered as a glutathione-dependent electron donor for ribonucleotide reductase in mutants lacking thioredoxin (Holmgren, 1976, 1979). Whereas thioredoxin and protein disulfide isomerase have broad substrate specificities (Mieyal et al., 1995) thioltransferase uses glutathione and specifically reduces glutathione-containing mixed disulfides with greater efficiency than does thioredoxin (Gravina and Mieyal, 1993; Chrestensen et al., 2000). Thioltransferase is a low molecular weight protein $(\sim 12 \mathrm{kDa}$; Gan and Wells, 1986; Mieyal et al., 1991), and recombinant human thioltransferase 
expressed and purified from Escherichia coli is identical to the natural enzyme (Chrestensen et al., 1995). Because thioltransferase is expressed constitutively in rat (Balijepalli et al., 1999) and human brain (Balijepalli et al., 2000), we examined its possible involvement in recovery of complex I activity after excitotoxic insult by L-BOAA.

\section{MATERIALS AND METHODS}

Materials. L-BOAA was obtained from Research Biochemicals (Natick, MA). Cysteinyl-glutathione disulfide was purchased from Toronto Research Chemicals (Toronto, Canada). TRI reagent was purchased from Molecular Research Center (Cincinnati, OH). Pure thioltransferase and antiserum to human red blood cell (RBC) thioltransferase were gifts of Prof. J. J. Mieyal (Case Western Reserve University, Cleveland, OH). Ubiquinone 1 was obtained from Eisai (Tokyo, Japan). Northern blot analysis was performed using digoxigenin-labeling kit from Boehringer Mannheim (Mannheim, Germany). Immunohistochemistry was performed using Vectastain $\mathrm{ABC}$ kit from Vector Laboratories (Burlingame, CA). Antibody to p-c-Jun, cJun, JunB, cFos, FosB and Fra-1 were purchased from Santa Cruz Biotechnology (Santa Cruz, CA). All other chemicals and reagents were of analytical grade and were obtained from Sigma (St. Louis, MO) or Qualigens (India).

Animals. Male Swiss albino mice (3-4 months old, 25-30 gm) were obtained from the National Institute of Mental Health and Neurosciences Animal Research Facility. Animals had ad libitum access to pelleted diet (Lipton, Calcutta, India) and water. All animal experiments were performed according to National Institutes of Health guidelines for care and use of laboratory animals. All efforts were made to minimize animal suffering, to reduce number of animals used, and to use alternatives to in vivo techniques, if available.

L-BOAA was dissolved in normal saline $(10 \mathrm{mg} / \mathrm{kg}$ body weight $)$ and administered subcutaneously to mice. In some experiments, $\alpha$-lipoic acid, a thiol antioxidant $(20 \mathrm{mg} / \mathrm{kg}$ body weight, s.c.) was given $1 \mathrm{hr}$ before L-BOAA treatment. Control animals received vehicle alone. Animals were killed at specified times, and brain and spinal cord were removed. The motor cortex was dissected from the brain (Sriram et al., 1998), the spinal cord was exposed, and thoracic and lumbosacral segments of the cord were harvested.

Processing of tissue. Tissues were removed immediately and processed for measurement of complex-I and thioltransferase activities and for estimation of glutathione and protein mixed glutathione disulfide levels. Tissue was homogenized in $0.25 \mathrm{M}$ sucrose and centrifuged at $1000 \times g$ for $10 \mathrm{~min}$ to obtain the postnuclear supernatant; it was again centrifuged at $14,000 \times g$ for $30 \mathrm{~min}$ to obtain the mitochondrial pellet. The yield of mitochondrial protein from lumbosacral cord and motor cortex of mice was $250-400 \mu \mathrm{g}$. The postmitochondrial supernatant was used for estimation of thioltransferase activity and immunoblot analysis. The mitochondrial pellet was suspended in sucrose $(0.25 \mathrm{M})$ and freeze-thawed for the assay of complex I. For the assay of GSH and protein glutathione mixed disulfide (PrSSG) tissues were frozen immediately in liquid nitrogen, weighed, and homogenized in nine volumes of $100 \mathrm{~mm}$ potassium phosphate buffer, pH 7.4, containing 1 mM EDTA. An aliquot of homogenate was added to equal volume of 5 -sulfosalicylic acid $(1 \%, \mathrm{w} / \mathrm{v})$, mixed, and centrifuged at $10,000 \times g$ for $10 \mathrm{~min}$, the supernatant was used for GSH estimation, and the acid-precipitated pellet was used for estimation of protein mixed glutathione disulfides.

Assay of NADH:ubiqninone oxidoreducatase (Complex I). Complex I was assayed in mitochondrial preparations as rotenone-sensitive NADHubiqinone oxidoreductase (Sriram et al., 1997). The assay was performed in $35 \mathrm{~mm}$ potassium phosphate buffer, $\mathrm{pH}$ 7.4, containing sodium cyanide $(2.65 \mathrm{~mm})$, magnesium chloride $(5 \mathrm{mM})$, EDTA $(1 \mathrm{mM})$, bovine serum albumin $(1 \mathrm{mg} / \mathrm{ml})$, and antimycin $(2 \mu \mathrm{g} / \mathrm{ml})$. Brain mitochondria $(70-80$ $\mu \mathrm{g})$ and ubiquinone $1(0.05 \mathrm{~mm})$ were added to the assay buffer to a final volume of $0.48 \mathrm{ml}$. After preincubation of the reaction mixture at room temperature for $2 \mathrm{~min}$, the reaction was initiated by addition $0.02 \mathrm{ml}$ of $5 \mathrm{~mm}$ NADH solution. Test and blank reactions were run separately using a single beam spectrophotometer. The rate of decrease of absorbance at $340 \mathrm{~nm}(0.04-0.09 / \mathrm{min})$ was monitored over $3 \mathrm{~min}$. The assay was also performed in the presence of rotenone to determine the rotenone-sensitive enzyme activity that was $80 \%$ of the total activity. The enzyme activity was expressed as nanomoles of NADH oxidized per minute per milligram of protein.

Assay of thioltransferase. Thioltransferase activity was estimated in postmitochondrial supernatant using cysteinyl-glutathione disulfide as substrate, according to Balijepalli et al. (1999). The postmitochondrial supernatant from brain region or spinal cord was suspended in $0.11 \mathrm{M}$ potassium phosphate buffer, $\mathrm{pH} 7.4$, containing $0.5 \mathrm{~mm}$ GSH, $24 \mathrm{U} / \mathrm{ml}$ glutathione reductase, and $3.5 \mathrm{~mm}$ NADPH. The reaction was initiated by addition of the substrate cysteinyl-glutathione disulfide $(100 \mathrm{mM})$. The decrease in absorbance of NADPH at $340 \mathrm{~nm}$ was measured for $3 \mathrm{~min}$. Blanks were run simultaneously without addition of postmitochondrial supernatant. The net enzymatic rate was obtained by subtraction of nonenzymatic rate from total rate. The enzyme activity was expressed as nanomoles of NADPH oxidized per minute per milligram of protein. The protein concentration was estimated by a dye-binding method (Bradford, 1976).

Estimation of glutathione. Total glutathione (GSH + GSSG) was estimated by the enzymatic recycling method (Tietze, 1969). The reaction mixture consisted of $100 \mathrm{~mm}$ potassium phosphate buffer, $\mathrm{pH} 7.4$, containing $0.8 \mathrm{~mm}$ dithiobisnitrobenzoic acid and $0.5 \mathrm{U} / \mathrm{ml}$ glutathione reductase in a total volume of $0.44 \mathrm{ml}$. The acid-soluble tissue supernatant $(0.01 \mathrm{ml})$ prepared as described above was added. The reaction was initiated by adding $0.05 \mathrm{ml}$ of $1.2 \mathrm{~mm}$ NADPH. The increase in absorbance was measured at $412 \mathrm{~nm}$ over $3 \mathrm{~min}$. A standard curve was generated using known amount of GSSG.

Estimation of protein glutathione mixed disulfides. The acid-precipitated pellet from CNS regions was washed with ethanol $(2 \times 1 \mathrm{ml})$ and sonicated for $5 \mathrm{~min}$. The pellet was resuspended in $50 \mathrm{~mm}$ 4-morpholinepropane sulfonic acid buffer, $\mathrm{pH} 8.0$, containing dithiothreitol (25 mM). The suspension was sonicated for $10 \mathrm{~min}$ and incubated in a shaker water bath for $1 \mathrm{hr}$ at $37^{\circ} \mathrm{C}$. Samples were deproteinized with $70 \%$ perchloric acid and centrifuged at $8000 \mathrm{rpm}$ for $10 \mathrm{~min}$. An aliquot of the supernatant was treated with $o$-pthaldialdehyde and reaction was kept in the dark for $10 \mathrm{~min}$. The fluorescence was recorded after excitation at 350 $\mathrm{nm}$ and emission at $420 \mathrm{~nm}$ (Akerboom and Sies, 1981; Ravindranath and Reed, 1990). A standard curve of GSH was also run simultaneously. The levels of GSH, GSSG, and PrSSG were validated by HPLC (Reed et al., 1980).

Immunoblot analysis. Pure thioltransferase (Mieyal et al., 1991) and postmitochondrial supernatant from the motor cortex and lumbosacral cord of vehicle- and L-BOAA-treated mice were subjected to SDS-PAGE gel electrophoresis, transferred to nitrocellulose membrane, and incubated with the antibody to human RBC thioltransferase (Mieyal et al., 1991), followed by incubation with anti-rabbit IgG labeled with alkaline phosphatase (Balijepalli et al., 1999). The immunostained bands were detected using nitroblue tetrazolium and 5-bromo-4-chloro-3-indolyl phosphate as chromogens.

Northern blotting. Total RNA from motor cortex and lumbosacral cord of vehicle and L-BOAA-treated mice was extracted using TRI reagent (Chomczynski, 1993). CNS regions from three animals were pooled for each sample preparation. Total RNA was separated electrophoretically and transferred to positively charged nylon membranes by capillary transfer, UV cross-linked, and hybridized with digoxigenin-labeled cRNA, prepared using the cDNA to brain thioltransferase (Balijepalli et al., 1999). The blots were washed, incubated with antibody to digoxigenin conjugated with alkaline phosphatase, and bands were visualized using chromogenic substrate for alkaline phosphatase.

In situ hybridization. Vehicle and L-BOAA-treated male Swiss albino mice were anesthetized with ether and perfused transcardially with normal saline followed by $4 \%$ paraformaldehyde $(\mathrm{w} / \mathrm{v})$ before the removal of the brain and spinal cord. Vibratome sections $(20-\mu \mathrm{m}$-thick) were cut in the coronal plane at the level of motor cortex and lumbar cord under RNase-free conditions. The sections were processed for in situ hybridization using digoxigenin-labeled sense and antisense cRNA probes, synthesized from cDNA to brain thioltransferase. After hybridization, the sections were washed and incubated with blocking reagent followed by antibody to digoxigenin conjugated to horseradish peroxidase and stained using diaminobenzidine and hydrogen peroxide for light microscopic observations.

Immunohistochemistry. Vibratome sections (30- $\mu \mathrm{m}$-thick) from vehicleand L-BOAA-treated mice were prepared as above and processed for immunohistochemical analysis using ABC Elite kit (Vector Laboratories), per the manufacturer's instructions. Sections were incubated with antiserum to human RBC thioltransferase (1:250 dilution in PBS) followed by incubation with biotinylated anti-rabbit IgG and avidin-biotin-peroxidase complex and visualized using diaminobenzidine and hydrogen peroxide.

Electrophoretic mobility shift assays. Nuclear extracts were prepared from motor cortex and lumbosacral cord from vehicle-treated, L-BOAAand $\alpha$-lipoic acid-treated, and L-BOAA-treated mice according to Korner 
et al. (1989). CNS regions from three animals were pooled for each sample preparation. The tissue was suspended in $10 \mathrm{~mm}$ HEPES, $\mathrm{pH}$ 7.9, containing $1.5 \mathrm{~mm}$ magnesium chloride, $10 \mathrm{~mm}$ potassium chloride, 0.5 $\mathrm{mm}$ phenylmethylsulfonyl fluoride, $1 \mu \mathrm{g} / \mathrm{ml}$ pepstatin A, $10 \mu \mathrm{g} / \mathrm{ml}$ leupeptin, and $10 \mu \mathrm{g} / \mathrm{ml}$ aprotinin and homogenized using a Dounce homogenizer. The samples were centrif uged at $1000 \times g$ for $10 \mathrm{~min}$, and the pellet was resuspended in $20 \mathrm{~mm}$ HEPES, $\mathrm{pH} 7.9$, containing $0.84 \mathrm{M}$ sodium chloride, $1.5 \mathrm{~mm}$ magnesium chloride, $0.4 \mathrm{~mm}$ EDTA, $0.5 \mathrm{~mm}$ dithiothreitol, and the above-mentioned protease inhibitors, incubated for $30 \mathrm{~min}$ at $4^{\circ} \mathrm{C}$, and centrifuged at $14,000 \times g$ for $15 \mathrm{~min}$. Aliquots of the supernatant containing the nuclear extract were frozen in liquid nitrogen and used for electrophoretic mobility shift assay.

Electrophoretic mobility shift and supershift assays were performed using the following consensus oligonucleotides: 5'-GATCGAGGGG ACTTTCCCTAGC - ' $^{\prime}$ and 3' $^{\prime}$-CTAGCTCCCCTGAAAGGGATCG-5' (NFkB); 5'-CTAGTGATGAGTCAGCCGGATC-3' and 3'-GATCAC TACTCAGTCGGCCTAG-5' (AP-1); and 5'-CGCGGGGCGCGTGA CTATGCGTGGGCTGGA-3' and ' $3^{\prime}$-GCGCCCCGCGCACTGATA CGCACCCGACCT-5' (ARE). Oligonucleotides were labeled with $\gamma$-[ $\left.{ }^{32} \mathrm{P}\right]$ ATP using polynucleotide kinase. Nuclear extracts were suspended in DNA binding buffer containing $10 \mathrm{~mm}$ Tris, $\mathrm{pH} 7.5,20 \mathrm{~mm}$ potassium chloride, $1 \mathrm{~mm}$ EDTA, $1 \mathrm{~mm} \beta$-mercaptoethanol, $4 \%(\mathrm{v} / \mathrm{v})$ glycerol, and protease inhibitors as mentioned before and incubated with each radiolabeled probe for $30 \mathrm{~min}$ at room temperature. Bound and free probes were separated by electrophoresis on a polyacrylamide gel in 44.5 mM Tris buffer, $\mathrm{pH} 8.0$, containing $44.5 \mathrm{~mm}$ borate and 1 mM EDTA. Gels were dried under vacuum, and radioactivity was detected using a PhosphorImager. Band specificity was determined by adding $50 \mathrm{M}$ excess of unlabeled probe to the nuclear extract before adding labeled probe. For supershift assays, nuclear extracts were incubated overnight with the specified antibody at $4^{\circ} \mathrm{C}$ before adding labeled oligonucleotides.

Downregulation of thioltransferase expression using antisense oligonucleotides. Phosphorothionate end-capped oligonucleotides (21 mer) originating from the start codon of thioltransferase cDNA (antisense: ATG GCT CAG GAG TTT GTG AAC; sense: TAC CGA GTC CTC AAA CAC TTA) were injected intrathecally into mice at $100 \mu \mathrm{g} /$ dose, twice at $12 \mathrm{hr}$ intervals. The downregulation of thioltransferase was examined by immunoblot analysis and enzyme activity measurement $12 \mathrm{hr}$ after the last injection of oligonucleotides. L-BOAA $(10 \mathrm{mg} / \mathrm{kg}$ body weight $)$ was administered $11 \mathrm{hr}$ after the second injection of the end-capped oligonucleotides, and the animals were killed $1 \mathrm{hr}$ after L-BOAA dosing. The motor cortex, thoracic, and lumbosacral segments of the spinal cord were dissected out, and the activities of complex I and thioltransferase were assayed as described earlier.

Statistical analysis was performed using Student's $t$ test or ANOVA followed by Student-Newman-Keuls or Dunnett's test as appropriate.

\section{RESULTS}

In the motor cortex (Fig. 1a) there was a significant decrease in GSH levels at 0.5 and $1 \mathrm{hr}$ after L-BOAA treatment that was accompanied by concomitant increase in PrSSG levels; both GSH and PrSSG levels recovered and were similar to control levels at $4 \mathrm{hr}$. The depleted GSH in both the CNS regions was recovered essentially as PrSSG and significant increase in GSSG levels was not seen as measured by HPLC (data not shown). Mice treated with L-BOAA showed a sustained decrease in GSH levels and increase in PrSSG levels up to $4 \mathrm{hr}$ in the lumbosacral segment of the spinal cord (Fig. 1b). The amount of GSH gained in lumbosacral cord as PrSSG at $0.5,1$, and $4 \mathrm{hr}$ after a single dose of BOAA was 133,150 , and $82 \%$ over and above the levels observed in control, respectively, whereas in the motor cortex, the levels were 140 and $121 \%$ at 0.5 and $1 \mathrm{hr}$, respectively. At the end of 4 hr, both GSH and PrSSG were restored to control levels in the motor cortex (Fig. 1a) but not in the lumbosacral cord. The total GSH recovered (sum of GSH equivalents recovered as GSH and PrSSG) at $1 \mathrm{hr}$ in motor cortex compared with vehicle-treated controls was $112 \%$ of control (Fig. 1a). In the lumbosacral cord, total GSH recovered was significantly greater than control $(119 \%)$ at $1 \mathrm{hr}($ Fig. $1 b)$.

The differential response to the thiol perturbation in the lum-
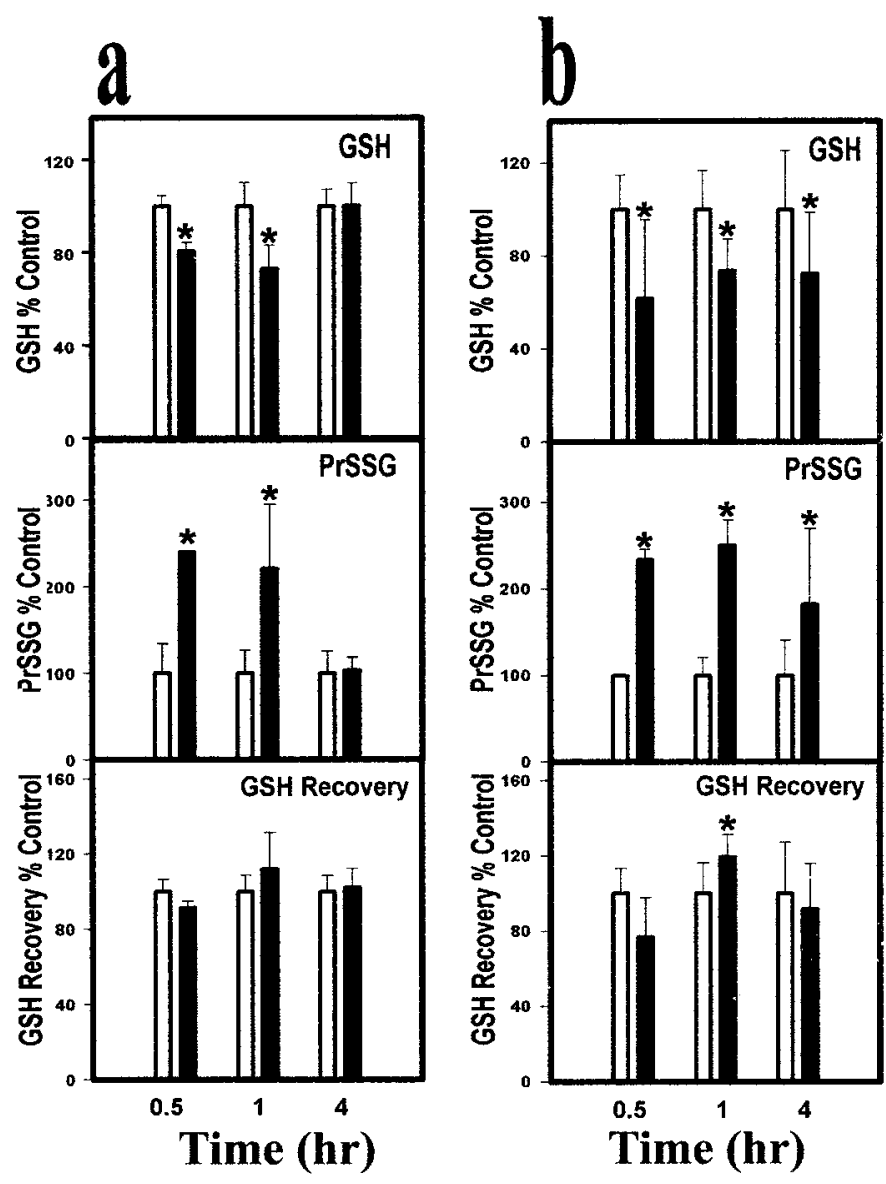

Figure 1. GSH and PrSSG levels in motor cortex $(a)$ and lumbosacral cord $(b)$ at various periods after a single dose of L-BOAA. L-BOAA (10 $\mathrm{mg} / \mathrm{kg}$ body weight, s.c.) was administered to mice, and animals were killed after $0.5,1$, and $4 \mathrm{hr}$ (black bars). Control animals received vehicle alone (white bars). GSH and PrSSG levels were estimated and are depicted as a percentage of corresponding controls. Total GSH recovered (sum of GSH equivalents recovered as GSH and as PrSSG) is also depicted. Values are mean $\pm \mathrm{SD}$ ( $n=3$ animals). GSH levels in motor cortex and lumbosacral cord from control animals were $22.51 \pm 0.823$ and $21.41 \pm 2.311 \mathrm{nmol} / \mathrm{mg}$ protein (equivalent to $1.54 \pm 0.017$ and $1.38 \pm$ $0.168 \mu \mathrm{mol}$ of GSH/gm tissue), respectively. PrSSG levels in motor cortex and lumbosacral cord of control animals were $1.71 \pm 0.076$ and $3.07 \pm$ $0.135 \mathrm{nmol}$ of $\mathrm{GSH}$ equivalents/mg protein (equivalent to $0.189 \pm 0.083$ and $0.203 \pm 0.048 \mu \mathrm{mol}$ of $\mathrm{GSH}$ equivalents/gm tissue), respectively. Asterisks indicate values significantly different from corresponding controls $(p<0.05)$.

bosacral cord and motor cortex was also reflected in the mitochondrial complex I activity after L-BOAA administration. Whereas a persistent decrease from $0.25-4 \mathrm{hr}$ was seen in complex I activity in the lumbosacral cord (Fig. 2, LSC), a significant decrease was seen in the motor cortex at $0.5 \mathrm{hr}$ after L-BOAA administration, and the enzyme activity rebounded to $125 \%$ of the control activity at $1 \mathrm{hr}$ (Fig. 2, MC). Because we had earlier observed that the inhibition of complex I activity was caused by protein thiol oxidation that could be restored in vitro by the disulfide reductant dithiothreitol (Sriram et al., 1998), we simultaneously examined the activity of thioltransferase in the CNS regions after L-BOAA treatment. Thioltransferase activity was increased and sustained by at least twofold in the motor cortex 1-4 hr after L-BOAA administration, thus paralleling the recovery of complex I in the motor cortex. In the lumbosacral cord, thioltransferase activity was increased significantly at 1 and $4 \mathrm{hr}$ 


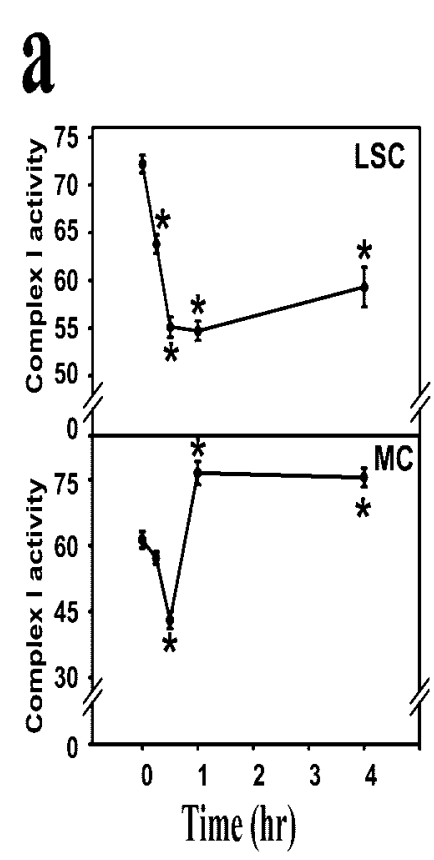

b

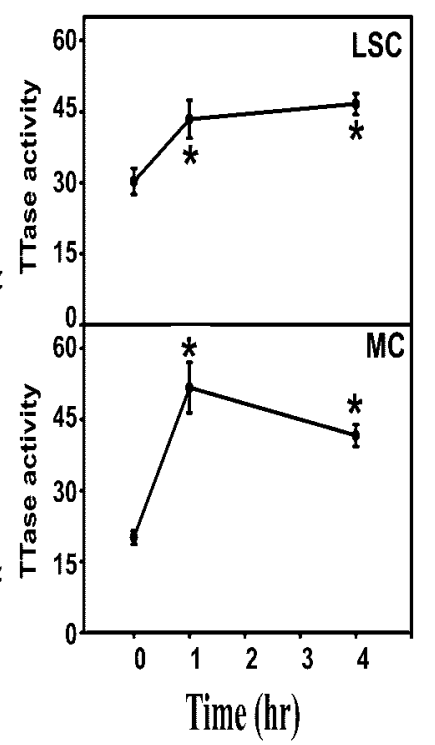

Figure 2. Complex I $(a)$ and thioltransferase $(b)$ activities in the motor cortex $(M C)$ and lumbosacral cord $(L S C)$ at various periods after a single dose of L-BOAA. Mice were administered L-BOAA $(10 \mathrm{mg} / \mathrm{kg}$ body weight, s.c.) and killed at indicated times. The control values were similar at all time points examined and are indicated as the zero hour value. Values are mean $\pm \operatorname{SEM}(n=6$ animals). Complex I activity is expressed as nanomoles of NADH oxidized per minute per milligram of protein, and thioltransferase activity is expressed as nanomoles of NADPH oxidized per minute per milligram of protein. Asterisks indicate values significantly different from corresponding controls $(p<0.05)$.

after L-BOAA administration (44.5 and 55.3\% higher than controls, respectively), but the increase was considerably lower compared with motor cortex and was not accompanied by recovery of complex I in the lumbosacral cord. In the thoracic segment of the spinal cord, which is unaffected by L-BOAA treatment, no change in GSH levels, complex I, and thioltransferase activities was observed as compared with vehicle-treated controls (data not shown).

To determine if the increase in thioltransferase activity was associated with increased expression of protein, immunoblot analysis was performed using antiserum to human RBC thioltransferase, which shares $100 \%$ homology with the brain thioltransferase (Chrestensen et al., 1995). Both the immunoblot analysis and immunohistochemistry revealed increased expression of thioltransferase protein (Fig. 3a,b). Although the thioltransferase activity in the motor cortex was increased to a greater extent than in the lumbar cord (Fig. 2), the immunoblot analysis seemed to indicate similar increase in thioltransferase protein in both the CNS regions. This may be attributable to the fact that the thioltransferase protein detected in the immunoblot would represent both the active form of the enzyme as well as the oxidized form of the enzyme containing disulfide groups. In the lumbar cord, there is sustained decrease in GSH levels and increase in protein glutathione mixed disulfides (Fig. 1) as compared with motor cortex. Increased protein immunostaining was seen in the neurons in the motor cortex and in the anterior horn cells in the lumbar cord (Fig. 3b) $1 \mathrm{hr}$ after administration of L-BOAA. This was associated with an upsurge in the transcription of thioltransferase mRNA as examined by Northern blotting (Fig. 4a) and in

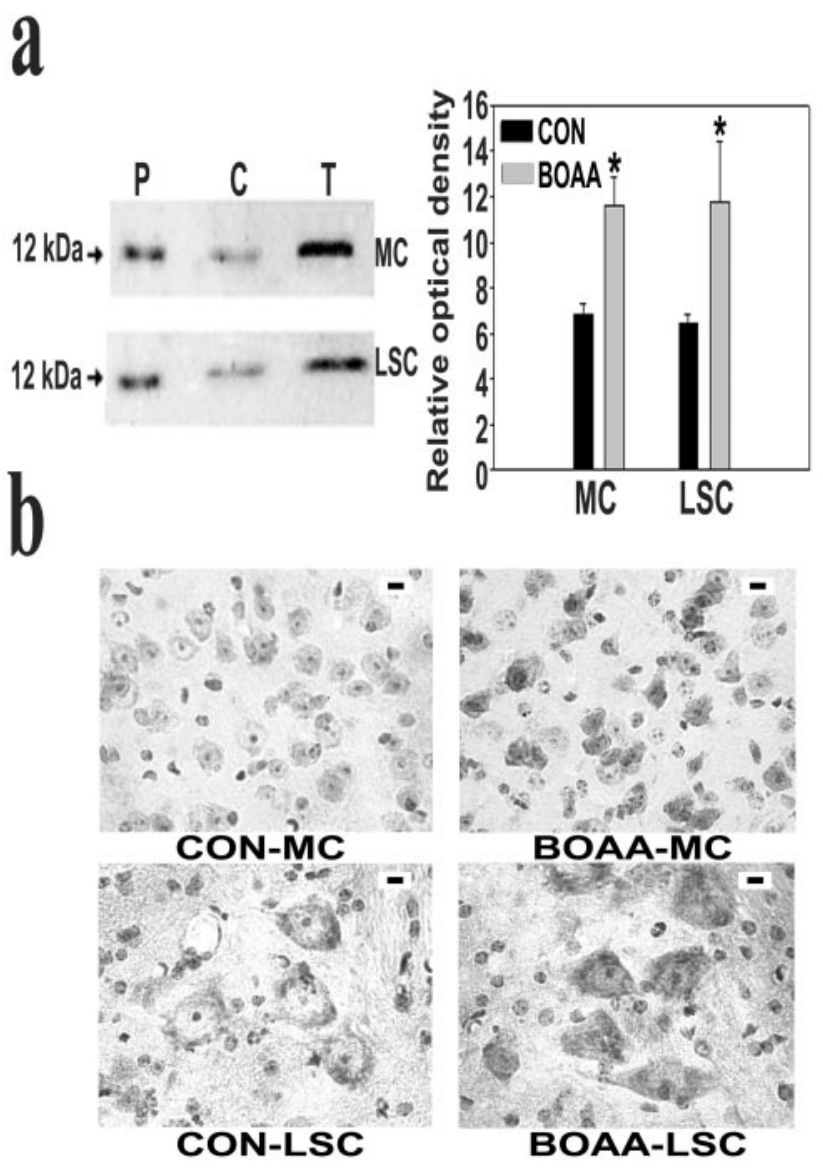

Figure 3. Expression of thioltransferase protein in mouse CNS after L-BOAA treatment. Mice were killed $1 \mathrm{hr}$ after L-BOAA administration. $a$, A representative blot from motor cortex $(M C)$ and lumbosacral cord $(L S C)$ from control $(C)$ and L-BOAA treated $(T)$ animals subjected to immunoblot analysis using antiserum to thioltransferase (lanes contained $10 \mu \mathrm{g}$ of protein). A sample of pure thioltransferase $(P, 10 \mathrm{ng})$ was also loaded on the same gel. Densitometric analysis of the immunoblots representing the relative intensity of the immunoreactive bands from control (black bars) and L-BOAA-treated animals (gray bars) are represented. Values are mean $\pm \mathrm{SD}(n=3$ animals). Asterisks indicate values significantly different from corresponding control $(p<0.05)$. $b$, Immunohistochemical localization of thioltransferase in motor cortex and lumbar cord revealed the increased levels of thioltransferase in the neurons in layer 3 of motor cortex $(B O A A-M C)$ and the anterior horn cells of the lumbar cord $(B O A A-L S C)$ as compared with untreated animals (CON-MC and $C O N$ - $L S C$ ) $1 \mathrm{hr}$ after a single dose of L-BOAA. Scale bar, $25 \mu \mathrm{m}$.

situ hybridization (Fig. 4b), $0.5 \mathrm{hr}$ after the administration of L-BOAA. Immunohistochemical localization and in situ hybridization experiments revealed increases in thioltransferase protein and mRNA in motor cortex neurons and anterior horn cells of the lumbar cord, the cells which are most affected by chronic L-BOAA treatment (Sriram et al., 1998).

$\alpha$-Lipoic acid, a thiol delivery agent, helps restore thiol homeostasis in brain (Panigrahi et al., 1996). Therefore, we examined the effect of pretreatment with $\alpha$-lipoic acid on L-BOAAinduced upregulation of thioltransferase. Administration of $\alpha$-lipoic acid (20 mg/kg body weight), $1 \mathrm{hr}$ before L-BOAA, abolished complex I inhibition in the lumbosacral cord (Fig. 5a). Furthermore, this pretreatment prevented the increase in expression of thioltransferase protein in the motor cortex usually seen after L-BOAA administration (Fig. 5b), although the activity of the enzyme showed a significant increase in the motor cortex (Fig. 
a

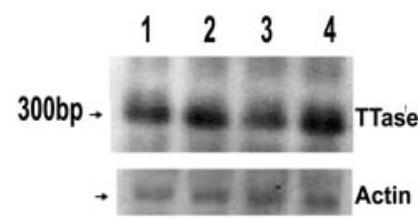

1

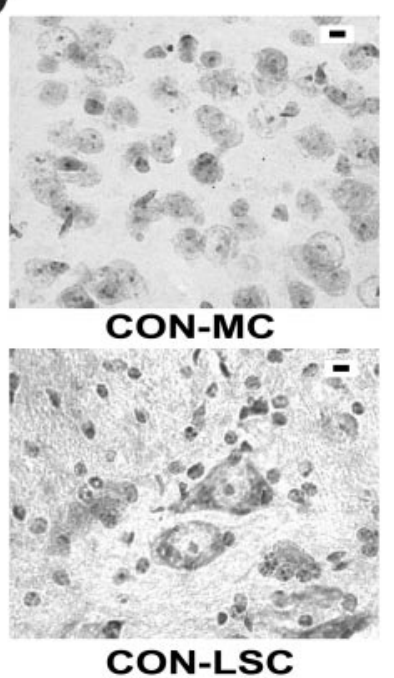

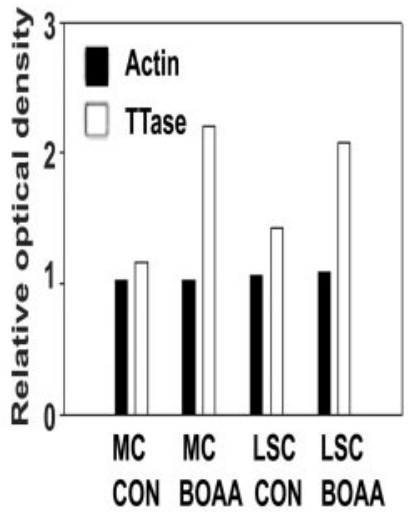

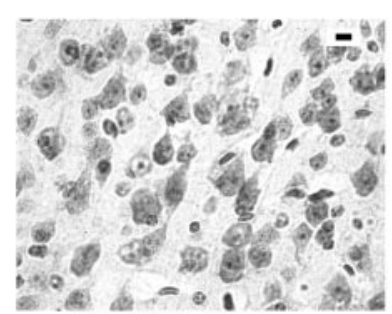

BOAA-MC

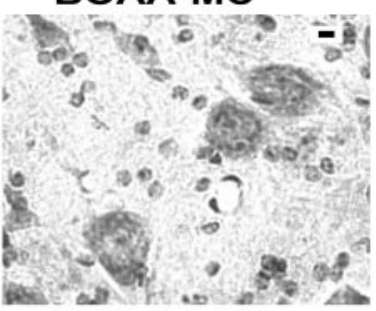

BOAA-LSC

Figure 4. Expression of thioltransferase mRNA in mouse CNS after L-BOAA treatment. Mice were administered L-BOAA and killed $0.5 \mathrm{hr}$ after L-BOAA. $a$, A representative Northern blot of the total RNA from motor cortex (lanes 1, 2; $10 \mu \mathrm{g}$ ) and lumbosacral cord (lanes 3, 4; $10 \mu \mathrm{g}$ ) from control (lanes 1, 3) and treated (lanes 2, 4) animals, respectively, subjected to Northern blot analysis using cRNA to brain thioltransferase (TTase). The blots were also hybridized with $\beta$-actin cRNA for normalization. Densitometric analyses of the Northern blots representing the relative intensity of the hybridized bands from $\beta$-actin (black bars) and thioltransferase (white bars) are represented. Values are means of two individual experiments using pooled brain regions from three animals. $b$, In situ hybridization of thioltransferase mRNA in motor cortex and lumbar cord revealed increased levels of thioltransferase in the neurons in layer 3 of motor cortex $(B O A A-M C)$ and the anterior horn cells of the lumbar cord $(B O A A-L S C)$ as compared with untreated animals $(C O N-M C$ and CON-LSC) $0.5 \mathrm{hr}$ after L-BOAA. Scale bar, $25 \mu \mathrm{m}$.

$5 a)$ of animals treated with $\alpha$-lipoic acid alone or with both $\alpha$-lipoic acid and L-BOAA, indicating that the increase in activity was presumably caused by post-translational effects such as maintenance of reduced thiol status of the enzyme.

Because a consensus sequence to the AP1 binding site is known to exist upstream of the thioltransferase gene, we examined the effect of L-BOAA on activation of AP1. In addition, we examined the activation of the transcription factors $\mathrm{ARE}$ and $\mathrm{NF} \kappa \mathrm{B}$ that are activated under oxidative stress (Radjendirane and Jaiswal, 1999; Zhou et al., 2002). Within 15 min after the administration of L-BOAA, significant increases in binding of AP1 and ARE (which share consensus binding sites) were observed in the motor cortex and lumbosacral cord (Fig. $6 a, b$ ), whereas $\mathrm{NF} \kappa \mathrm{B}$ was
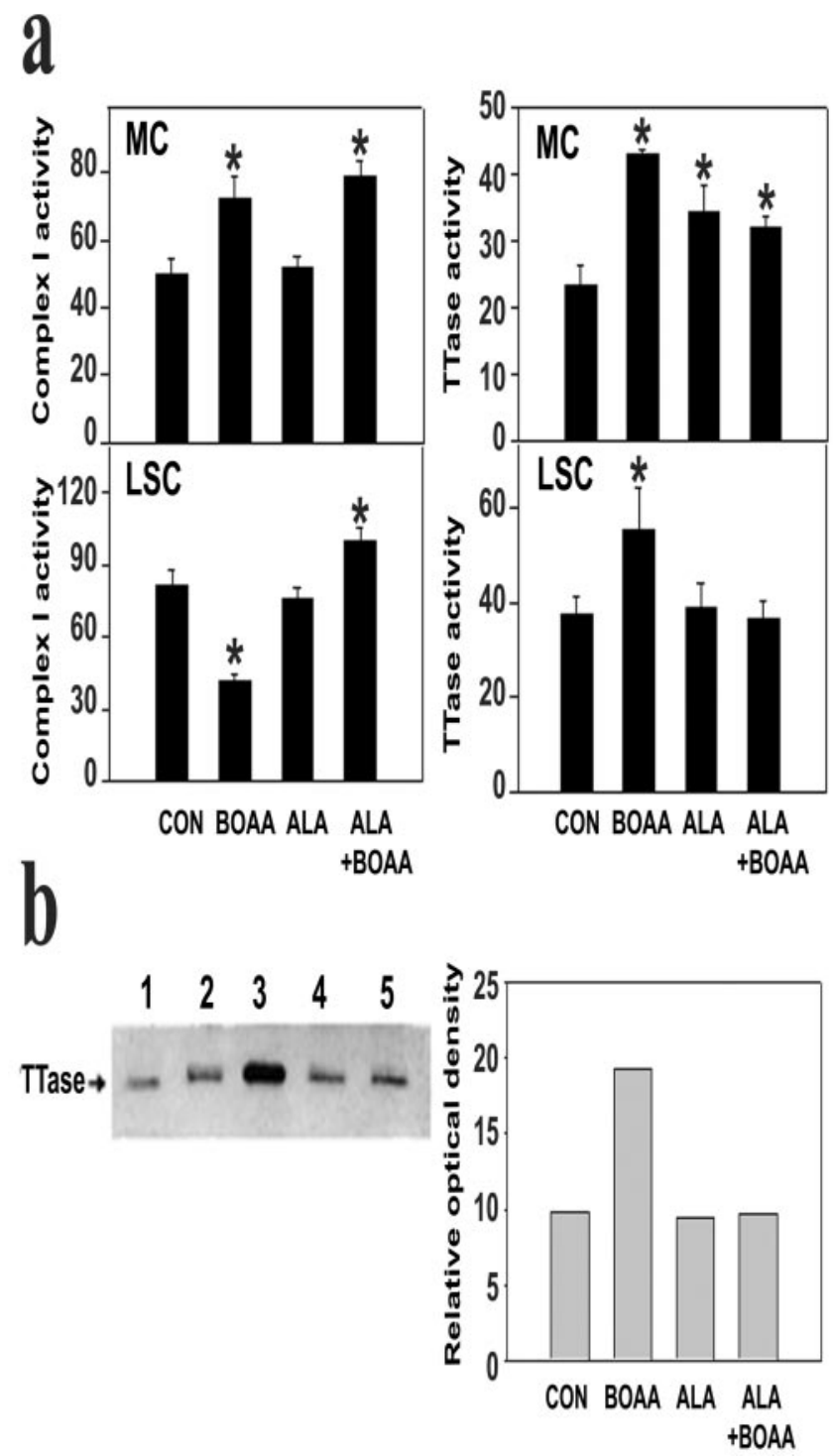

Figure 5. Effect of $\alpha$-lipoic acid pretreatment on L-BOAA-mediated inhibition of complex I activity and upregulation thioltransferase in mouse CNS. Animals were pretreated with $\alpha$-lipoic acid $(20 \mathrm{mg} / \mathrm{kg}$ body weight, s.c.) $1 \mathrm{hr}$ before administration of L-BOAA $(10 \mathrm{mg} / \mathrm{kg}$ body weight, s.c.) and killed $1 \mathrm{hr}$ after the L-BOAA dose. $a$, Activities of complex I and thioltransferase were measured in the motor cortex and lumbosacral cord as described under Figure 1. Values are mean $\pm \mathrm{SD}$ $(n=6$ animals, and asterisks indicate values significantly different from vehicle-treated controls) $(p<0.05) . b$, A representative blot from motor cortex $(10 \mu \mathrm{g})$ of animals treated with vehicle (lane 2), L-BOAA (lane 3), $\alpha$-lipoic acid (lane 4), and $\alpha$-lipoic acid and L-BOAA (lane 5) subjected to immunoblot analysis using antiserum to thioltransferase. A sample of pure thioltransferase (lane 1, $10 \mathrm{ng}$ ) was also loaded on the same gel. Densitometric analyses of immunoblots representing relative intensity of immunoreactive bands are represented. Values are mean of two individual experiments.

unaffected (Fig. 6c). Pretreatment of animals with $\alpha$-lipoic acid prevented L-BOAA activation of both AP1 and ARE. The activation of AP1 was supershifted by antibody to phosphorylated cJun (Fig. 6d), but was unaffected by antibody to JunB, cFos, FosB, and Fra-1 (data not shown). Thus, within 15 min after L-BOAA administration, activation of transcription factor AP1 occurred, followed within $30 \mathrm{~min}$ by increased transcription of thioltransferase mRNA, and within $1 \mathrm{hr}$ after L-BOAA adminis- 


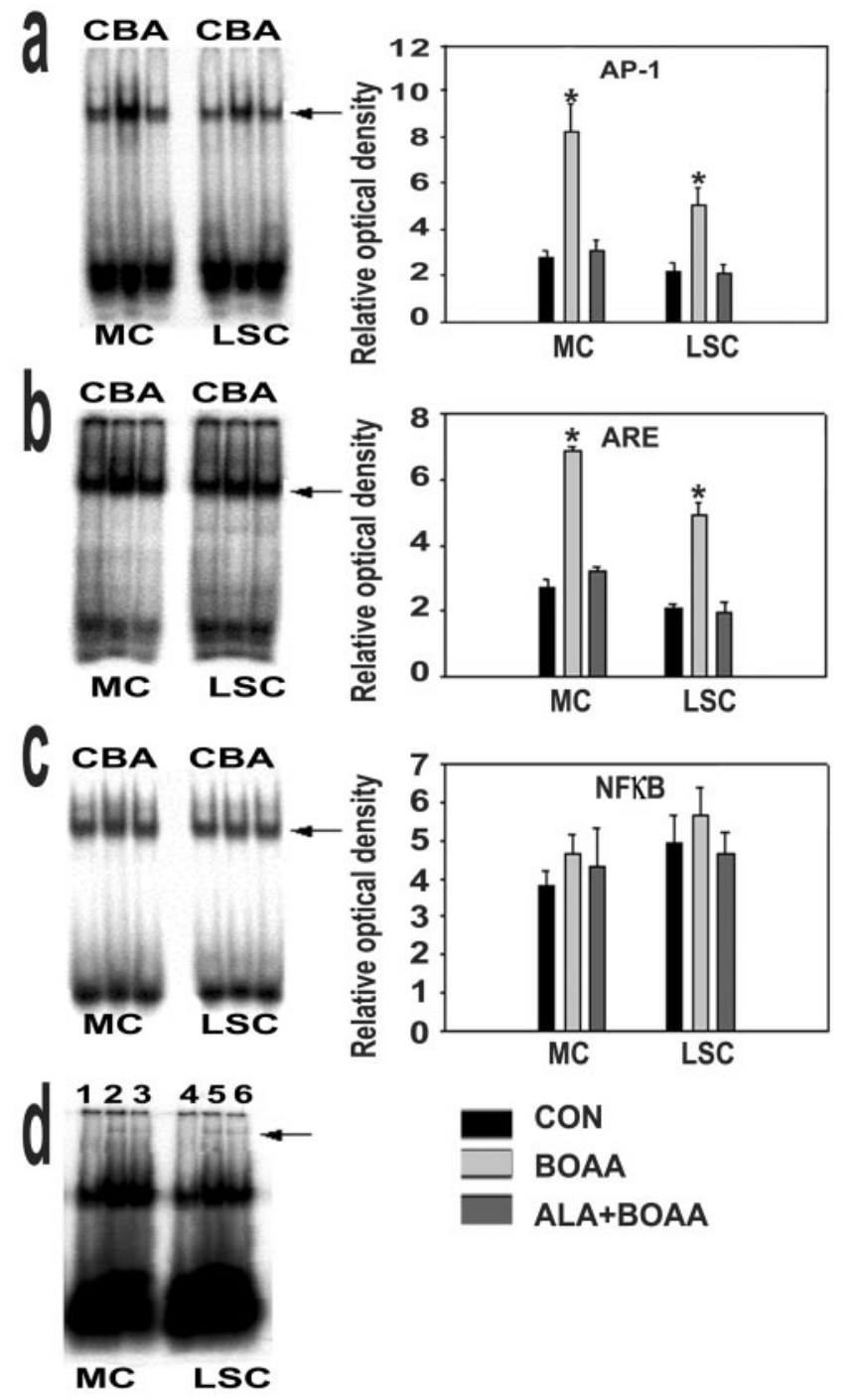

Figure 6. Activation of transcription factors AP1 (a), ARE (b), and $\mathrm{NF}-\kappa \mathrm{B}(c)$ after administration of L-BOAA to mice. Mice were administered L-BOAA and killed 15 min after L-BOAA. Electrophoretic mobility shift assays were performed using nuclear extracts ( $5 \mu \mathrm{g}$ of protein) from motor cortex $(M C)$ and lumbar sacral cord $(L S C)$ of mice treated with vehicle $(C)$, L-BOAA $(B)$, and $\alpha$-lipoic acid and L-BOAA $(A)$. Densitometric analyses of the shifted bands representing the relative intensity of binding of transcription factors are represented. Values are mean of three individual experiments. $d$, Antibody to phosphorylated cJun super shifts the mobility of the transcription factors AP1 after administration of L-BOAA to mice. The nuclear extracts from motor cortex (MC; lanes 1-3) and lumbar sacral cord (LSC; lanes 4-6) of mice treated with vehicle (lanes 1, 4) and L-BOAA (lanes 2, 3, 5, 6) were preincubated with antibody to phosphorylated $\mathrm{c}$ Jun before performing electrophoretic mobility shift assay as described above.

tration, by the increased expression of thioltransferase protein and activity.

To further confirm the role of thioltransferase in the recovery of complex I after L-BOAA administration, we administered antisense oligonucleotides to downregulate thioltransferase, and we examined the effect on the recovery of mitochondrial function. The oligonucleotides were injected intrathecally to ensure the selective downregulation of thioltransferase in the CNS. Injection of $200 \mu \mathrm{g}$ of antisense oligonucleotides in two divided doses of $100 \mu \mathrm{g}$ at $12 \mathrm{hr}$ intervals resulted in the downregulation of

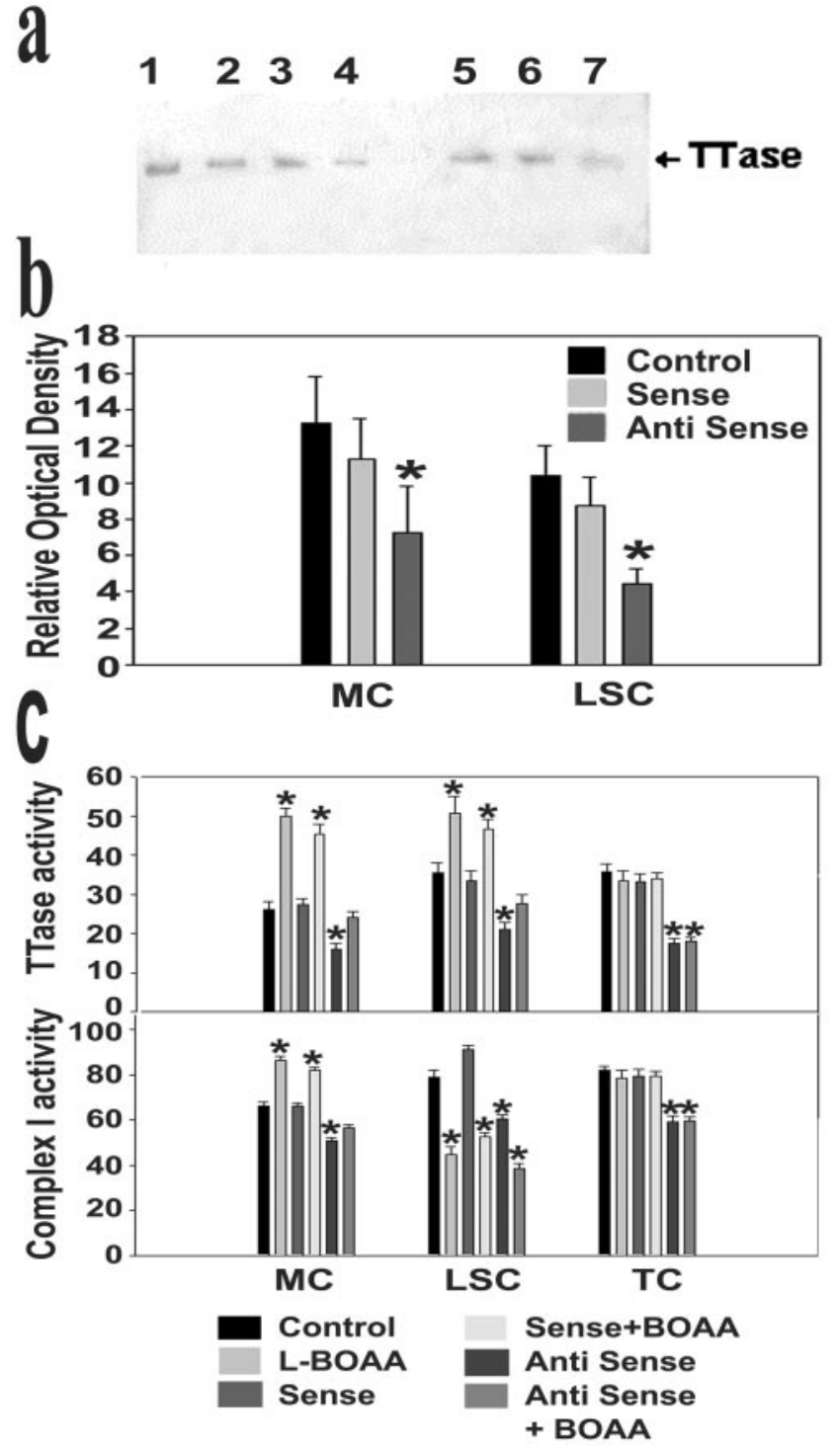

Figure 7. Effect of downregulation of thioltransferase protein using antisense oligonucleotides on L-BOAA-mediated mitochondrial dysfunction. Mice were injected intrathecally with sense and antisense oligonucleotides and killed $12 \mathrm{hr}$ after the last injection. $a$, Immunoblot analysis of thioltransferase protein from motor cortex (lanes 2-4) and lumbosacral cord (lanes 5-7) from vehicle (lanes 2, 5), sense oligonucleotide-treated (lanes 3, 6), and antisense oligonucleotide-treated (lanes 4, 7) immunostained with antiserum to RBC thioltransferase (lanes contained $10 \mu \mathrm{g}$ of protein). Lane 1 contained $10 \mathrm{ng}$ of pure thioltransferase. $b$ Represents the densitometric analysis of the immunoblots from three animals. Values are mean $\pm \mathrm{SD}(n=3$ animals $)$. $c$, Thioltransferase and complex I activities in motor cortex $(M C)$, lumbosacral cord $(L S C)$, and thoracic cord $(T C)$ of animals treated with sense or antisense oligonucleotides (as described above) followed by L-BOAA administration and killed after 1 hr. Values are mean \pm SD $(n=5-6)$ animals. Asterisks indicate values significantly different from vehicle-treated control $(p<0.05)$.

thioltransferase expression in the motor cortex (42\%) and lumbosacral cord $(46 \%)$ at $12 \mathrm{hr}$ after the last injection (Fig. 7a,b). The sense oligonucleotides had no effect on the enzyme activity. L-BOAA was administered $11 \mathrm{hr}$ after the second injection of oligonucleotides to three sets of animals: vehicle-treated, sense, or antisense oligonucleotide-treated, and the animals were killed 1 hr later. This time period of L-BOAA exposure was chosen, 
because the rebound in complex I activity is seen in the motor cortex $1 \mathrm{hr}$ after L-BOAA, and the effect of downregulation of thioltransferase on the recovery of complex I could be examined. Thioltransferase and complex I activity was measured in the motor cortex, lumbosacral cord, and the thoracic cord, which is unaffected by L-BOAA. Antisense oligonucleotides completely abolished the recovery of complex $\mathrm{I}$ in the motor cortex that otherwise would have occurred within $1 \mathrm{hr}$ after L-BOAA administration, whereas the sense nucleotides had no significant effect. Downregulation of thioltransferase by itself (without L-BOAA challenge) resulted in significant inhibition of complex I both in motor cortex and lumbosacral cord (Fig. $7 c$ ), indicating the critical role of this enzyme in maintaining mitochondrial function. In the lumbosacral cord, antisense oligonucleotides further inhibited complex I as compared with L-BOAA alone. Mitochondrial function in the thoracic cord was unaffected by L-BOAA, and there was no significant difference between the groups of animals treated with the vehicle, sense, or antisense oligonucleotides as compared with those treated additionally with L-BOAA. However, complex I activity was significantly decreased in the antisense oligonucleotide-treated group, similar to that seen in motor cortex and lumbosacral cord (Fig. 7c).

\section{DISCUSSION}

Chronic administration of L-BOAA to mice for $40 \mathrm{~d}$ results in cell loss in motor cortex and lumbosacral cord (Sriram et al., 1998). In the present study we administered a single dose of L-BOAA that does not cause any detectable irreversible damage to neuronal cells to study early events after exposure to the excitotoxin.

We demonstrate herein that the rebound of complex I (125\% of control level) in the motor cortex after the initial inhibition caused by L-BOAA is associated with up-regulation of thioltransferase. The increase in thioltransferase activity was specific to the motor cortex and lumbosacral cord (where complex I is inhibited by L-BOAA), whereas it was unchanged in the thoracic cord (the CNS region unaffected by L-BOAA). The cascade of events that occurs after a single subcutaneously administered dose of L-BOAA consists of activation of the transcription factor AP1, mediated through phosphorylated cJun, within $15 \mathrm{~min}$, followed by upregulation of thioltransferase mRNA by $30 \mathrm{~min}$, and increase in the thioltransferase protein, both in the motor cortex and lumbosacral segment of the spinal cord, within $1 \mathrm{hr}$. The degree of upregulation of thioltransferase was substantially greater in motor cortex as compared with the lumbosacral cord (Figs. 2-4). Furthermore, the 2.5-fold increase in thioltransferase activity in motor cortex was accompanied by full rebound of complex I activity. In the lumbosacral cord the increase in thioltransferase was less (1.5-fold), and the complex I activity did not fully recover to control levels, possibly because of an insufficient upregulation of thioltransferase. Additionally, there was sustained loss of GSH in the lumbosacral cord up to $4 \mathrm{hr}$ after the single dose of L-BOAA, whereas in motor cortex there was only a transient loss of the tripeptide (Fig. 1). In the motor cortex, thiol homeostasis was restored within $4 \mathrm{hr}$ while there was sustained perturbation in the lumbosacral cord (Fig. 1). Sustained loss of GSH can lead to inactivation of protein, including thioltransferase, through glutathionylation. GSH is essential for thioltransferase activity; indeed, deprivation of cellular GSH results in decreased thioltransferase activity (Chrestensen et al., 2000). Thus, lowered levels of GSH in lumbosacral cord could be responsible for attenuation of the upregulation of thioltransferase. Loss of cellular GSH was shown to have a direct effect on complex I activity in pheochromocytoma cell line 12 cells treated with buthionine sulfoximine (Davey et al., 1998). Additionally, downregulation of GSH through doxycycline-mediated induction of antisense messages against $\gamma$-glutamyl-cysteine synthetase (the rate-limiting enzyme in GSH synthesis) results in loss of mitochondrial GSH and decreased mitochondrial function through selective inhibition of complex I (Jha et al., 2000). Complex I has several cysteine residues in its active site (Dupuis et al., 1991), and the facile glutathionylation of thiol groups therein by oxidative stress can potentially result in inhibition of the enzyme.

The preferential and often reversible $S$-glutathionylation of proteins that occurs during oxidative stress has been suggested to be a protective mechanism in brain (Ehrhart and Zeevalk, 2001). Thioltransferase efficiently and selectively reduces protein glutathione mixed disulfides to protein thiols in the presence of GSH (Mieyal et al., 1995). We hypothesized that since formation of protein glutathione mixed disulfides is one of the major consequences of oxidative stress in brain, thioltransferase could potentially play an important role during neuronal recovery from oxidative stress by restoring protein thiol homeostasis. We, therefore, examined the regulation of thioltransferase during recovery of mitochondrial function after an excitotoxic insult and discovered its upregulation. Although the enzymatic function of thioltransferase was discovered more than 25 years ago (Mannervik and Axelsson, 1975) and its potential role in repair of oxidative damage has been postulated (Holmgren, 1989; Mieyal et al., 1995), the present study provides the first evidence for its differential regulation at the transcriptional level during CNS recovery from oxidative stress. Thus, presumably after a perturbation in the thiol status, the transcription of thioltransferase mRNA is upregulated within a relatively short time after a systemic dose of L-BOAA. Upstream of the thioltransferase gene there is an AP1 transcription factor binding site, and transfection of this promoter region along with a luciferase reporter results in higher luciferase activity, indicating that transcription of thioltransferase is mediated through AP1 (Park and Levine, 1997). We examined AP1mediated transcription and found it to be activated within $15 \mathrm{~min}$ of L-BOAA administration, after which the sequential upregulation of thioltransferase mRNA and protein occurred (Figs. 2-4). It has been suggested that thioltransferase might regulate the transcriptional activity of AP1 through activation of the Jun N-terminal kinase (JNK) cascade (Daily et al., 2001), thereby protecting cerebellar granule neurons in culture. Activation of the JNK signaling cascade that converges on the phosphorylation of cJun has also been associated with the induction of apoptosis in MPTP-treated mice (Xia et al., 2001). However, in the present study we show that within 15 min after a single systemic administration of the excitatory amino acid, L-BOAA, the phosphorylation of cJun and its translocation to the nucleus occurs and is accompanied by activation of AP1, leading to increased transcription of thioltransferase mRNA. The experiments using antisense oligonucleotides provided further confirmation of thioltransferase involvement in the functional recovery of protein thiols after oxidative insult. Treatment with thioltransferase antisense oligonucleotides alone resulted in significant decrease in complex I activity in all the three CNS regions examined, including the thoracic cord which is unaffected by L-BOAA, indicating the important role played by thioltransferase in the maintenance of mitochondrial function. Although the critical role played by GSH in maintaining complex I activity has been demonstrated earlier, this is the first evidence demonstrating the importance of thioltransferase in maintaining mitochondrial complex I function, 
presumably through the regeneration of thiol moiety that undergo glutathionylation.

The majority of cellular thioltransferase (Grx1) is localized in the cytosol, however recently a mitochondrial form of thioltransferase (Grx2; Gladyshev et al., 2001; Lundberg et al., 2001) has been reported that shares very little sequence identity to Grx1, and their antibodies do not cross-react. The antisense oligonucleotide sequence used in the present study to downregulate Grx1 shared no homology with Grx2. The cDNA and antibody used in the present study correspond to the cytosolic form of thioltransferase Grx1 (Chrestensen et al., 1995). However, a portion of the cytosolic form of thioltransferase (Grx1) also has been found in isolated rat heart mitochondria (Vazquez et al., 2001). Furthermore, an analogous finding that a fraction of the yeast cytosolic $\mathrm{Cu}-\mathrm{Zn}$ superoxide dismutase is localized to the intermembrane space of mitochondria was reported recently (Sturtz et al., 2001). Thus, the transcriptional upregulation of thioltransferase seen in the present study might represent the Grx1 present in both cytosol and mitochondria.

Complex I abnormalities have also been observed in other neurodegenerative disorders. Earlier studies using MPTP, a neurotoxin that causes Parkinson-like symptoms in primates, have helped to identify abnormalities in complex I in mitochondria from platelets, brain, and muscle of Parkinson's disease patients (Parker et al., 1989; Mizuno et al., 1995). There is evidence that mitochondrial complex I dysfunction is a consequence of stress oxidation of critical thiol groups in the enzyme (Sriram et al., 1997, 1998; Jha et al., 2000). In addition, inhibition of complex I activity mediated by a single dose of MPTP can be reversed in vitro by treatment of brain mitochondria with the disulfide reductant dithiothreitol, indicating that thiol oxidation may be a primary cause for loss in activity, although complex I activity may not be reversible in chronic models of MPTP toxicity (Annepu and Ravindranath, 2000). Thus, the implications of the present results might be extendable to complex I abnormalities seen in animal models of Parkinson's disease, where also thioltransferase may play a key role in recovery of mitochondrial function.

Whereas upregulation of thioltransferase leads to recovery from mitochondrial injury after subacute insult, sustained upregulation of the enzyme may be required to prevent the damage that occurs after chronic insult. Another approach for protection of mitochondria during chronic insult could potentially involve the use of thiol delivery agents such as $\alpha$-lipoic acid. As shown in the present study, previous treatment with $\alpha$-lipoic acid not only prevents mitochondrial dysfunction but also abolishes the early response of AP1 activation after L-BOAA administration. Furthermore, administration of $\alpha$-lipoic acid elevates thioltransferase activity in motor cortex presumably through maintenance of thiol status, because the expression of thioltransferase protein is unaffected (Fig. 5). $\alpha$-Lipoic acid administration has recently been shown to help maintain mitochondrial integrity and prevent ageassociated mitochondrial oxidative decay (Liu et al., 2002). In conclusion, we demonstrate that thioltransferase mediates recovery of brain mitochondria from oxidative damage caused by protein- $S$-glutathionylation and further provide evidence for an essential function of thioltransferase during recovery from oxidative damage.

\section{REFERENCES}

Akerboom TP, Sies H (1981) Assay of glutathione, glutathione disulfide and glutathione mixed disulfides in biological samples. Methods Enzymol 77:373-382.

Annepu J, Ravindranath V (2000) 1-Methyl-4-phenyl-1, 2, 3, 6 tetrahy- dropyridine induced complex I inhibition is reversed by disulfide reductant, dithiothreitol in mouse brain. Neurosci Lett 289:209-212.

Balijepalli S, Tirumalai PS, Swamy KV, Boyd MR, Mieyal JJ, Ravindranath V (1999) Rat brain thioltransferase: regional distribution, immunological characterization and localization by fluorescent in situ hybridization. J Neurochem 72:1170-1178.

Balijepalli S, Boyd MR, Ravindranath V (2000) Human brain thioltransferase: constitutive expression and localization by fluorescent in situ hybridization. Mol Brain Res 85:123-132.

Bradford MM (1976) A rapid and sensitive method for the quantitation of microgram quantities of protein utilizing the principle of dyebinding. Anal Biochem 72:248-254.

Chomczynski PA (1993) Reagent for the single step simultaneous isolation of RNA, DNA and protein from cell and tissue samples. Biotechniques 15:532-537.

Chrestensen CA, Echman CB, Starke DW, Mieyal JJ (1995) Cloning expression and characterization of human thioltransferase (glutaredoxin) in E. coli. FEBS Lett 374:25-28.

Chrestensen CA, Starke DW, Mieyal JJ (2000) Acute cadmium exposure inactivates thioltransferase (Glutaredoxin), inhibits intracellular reduction of protein-glutathionyl-mixed disulfides, and initiates apoptosis. J Biol Chem 275:26556-26565.

Cohn DF, Streifler M (1981) Human neurolathyrism, a follow-up study of 200 patients. Part I: Clinical Investigation. Schweiz. Arch Neurol Neurochir Psychiatr 128:151-156.

Daily D, Vlamis-Gardikas A, Offen D, Mittelman L, Melamed E, Holmgren A, Barzilai A (2001) Glutaredoxin protects cerebellar granule neurons from dopamine-induced apoptosis by dual activation of the ras-phosphoinositide 3-kinase and jun-N-terminal kinase pathways. J Biol Chem 276:21618-21626.

Davey GP, Peuchen S, Clark JB (1998) Energy thresholds in brain mitochondria: potential involvement in neurodegeneration. J Biol Chem 273:12753-12757.

Dupuis A, Skehel JM, Walker JE (1991) NADH: ubiquinone oxidoreductase from bovine mitochondria. cDNA sequence of $19 \mathrm{kDa}$ cysteine rich subunit. Biochem J 277:11-15.

Ehrhart J, Zeevalk GD (2001) Hydrogen peroxide removal and glutathione mixed disulphide formation during metabolic inhibition in mesencephalic cultures. J Neurochem 77:1496-1507.

Gan ZR, Wells WW (1986) Purification and properties of thioltransferase. J Biol Chem 261:996-1001.

Gladyshev VN, Liu A, Novoselov SV, Krysan K, Sun QA, Kryukov VM, Kryukov GV, Lou MF (2001) Identification and characterization of a new mammalian glutaredoxin (thioltransferase) Grx2. J Biol Chem 276:30374-30380.

Gravina SA, Mieyal JJ (1993) Thioltransferase is a specific glutathionyl mixed disulphide oxidoreductase. Biochemistry 32:3368-3376.

Holmgren A (1976) Hydrogen donor system for E. coli ribonucleotiside diphosphate reductase dependent upon glutathione. Proc Natl Acad Sci USA 73:2275-2279.

Holmgren A (1979) Glutathione dependent synthesis of deoxy ribonucleotides, characterization of the enzymatic mechanism of E. coli glutaredoxin. J Biol Chem 254:3672-3678.

Holmgren A (1989) Thioredoxin and glutaredoxin systems. J Biol Chem 264:13963-13966.

Jha N, Jurma O, Lalli G, Liu Y, Pettus EH, Greenamyre JT, Liu RM, Forman HJ, Andersen JK (2000) Glutathione depletion in PC12 results in selective inhibition of mitochondrial complex I activity. Implications for Parkinson's disease. J Biol Chem 275:26096-26101.

Korner M, Rattner A, Mauxion R, Sen R, Citri Y (1989) A brainspecific transcription activator. Neuron 3:563-572.

Liu J, Head E, Gharib AM, Yuan W, Ingersoll RT, Hagen TM, Cotman CW, Ames BN (2002) Memory loss in old rats is associated with brain mitochondrial decay and RNA/DNA oxidation: partial reversal by feeding acetyl-L-carnitine and/or R- $\alpha$-lipoic acid. Proc Natl Acad Sci USA 99:2356-2361.

Lopachin RM (1999) Intraneuronal ion distribution during experimental oxygen/glucose deprivation. Routes of ion fluxes as targets of neuroprotective strategies. Ann NY Acad Sci 890:191-203.

Lundberg M, Johansson C, Chandra J, Enoksson M, Jacobsson G, Ljung J, Johansson M, Holmgren A (2001) Cloning and expression of a novel human glutaredoxin (Grx2) with mitochondrial and nuclear isoforms. J Biol Chem 276:26269-26275.

Mannervik B, Axelsson K (1975) Reduction of disulphide bonds in proteins mixed disulphides catalysed by a thioltransferase in rat liver cytosol. Biochem J 149:785-788.

Mieyal JJ, Starke DW, Gravina SA, Dothey C, Chung J (1991) Thioltransferase in human red blood cells: purification and properties. Biochemistry 30:6088-6097.

Mieyal JJ, Srinivasan V, Starke DW, Gravina SA, Mieyal P (1995) Glutathionyl specificity of thioltransferase: mechanistic and physiological implications. In: Biothiols in health and disease (Packer L, Cadenas E, eds) pp 305-372. New York: Marcel Decker.

Mizuno Y, Ikebe S, Hattori N, Nakagawa-Hattori Y, Mochizuki H, Tanaka M, Ozawa T (1995) Role of mitochondria in the etiology and 
pathogenesis of Parkinson's disease. Biochim Biophys Acta 1271: 265-274.

Panigrahi M, Sadguna Y, Shivakumar BR, Kolluri SVR, Roy S, Packer L, Ravindranath V (1996) Alpha lipoic acid protects against reperfusion injury following cerebral ischemia in rats. Brain Res 717:184-188.

Park JB, Levine M (1997) The human glutaredoxin gene: determination of its organization, transcription start point and promoter analysis. Gene 197:189-193.

Parker WD, Boyson SJ, Parke JK (1989) Abnormalities of the electron transport chain in idiopathic Parkinson's disease. Ann Neurol 26: $719-723$

Pearson S, Nunn PB (1981) The neurolathyrogen $\beta$-N-oxalyl-L- $\alpha$, $\beta$-diaminopropionic acid, is a potent agonist at "glutamate preferring" receptors in frog spinal cord. Brain Res 206:178-182.

Radjendirane V, Jaiswal AK (1999) Antioxidant response element mediated 2, 3, 7, 8-tetrachlorodibenzo-p-dioxin (TCDD) induction of human NAD $(P) H$ : ubiquinone oxidoreductase 1 gene expression. Biochem Pharmacol 58:1649-1655.

Rao SLN, Adiga PR, Sarma PS (1964) The isolation and characterization of $\beta$ - $N$-oxalyl-L- $\alpha, \beta$-diaminopropionic acid: a neurotoxin from the seeds of Lathyrus sativus. Biochemistry 3:432-436.

Ravindranath V, Reed DJ (1990) Glutathione depletion and formation of glutathione-protein mixed disulphide following exposure of brain mitochondria to oxidative stress. Biochem Biophys Res Commun 169:1075-1079.

Reed DJ, Babson JR, Beatty PW, Brodie AE, Ellis WW, Potter DW (1980) High-performance liquid chromatography analysis of nanomole levels of glutathione, glutathione disulfide and related thiols and disulfides. Anal Biochem 106:55-62.

Rokutan K, Johnston RB, Kawai K (1994) Oxidative stress induces protein $S$-thiolation of specific proteins in cultured gastric mucosal cells. Am J Physiol 266:G247-G254.

Ross SM, Roy DN, Spencer PS (1989) $\beta$ - $N$-oxalylamino-L-alanine action on glutamate receptors. J Neurochem 53:710-715.

Schuppe I, Moldeus P, Cotgreave IA (1992) Protein-specific $S$-thiolation in human endothelial cells during oxidative stress. Biochem Pharmacol 44:1757-1764.

Selye H (1957) Lathyrism. Rev Can Biol 16:1-2.
Shivakumar BR, Ravindranath V (1992) Oxidative stress induced by administration of the neuroleptic drug haloperidol is attenuated by higher doses of haloperidol. Brain Res 595:256-262.

Shivakumar BR, Kolluri SVR, Ravindranath V (1995) Glutathione and protein thiol homeostasis in brain during reperfusion following cerebral ischemia. J Pharmacol Exp Ther 274:1167-1173.

Sriram K, Pai KS, Boyd MR, Ravindranath V (1997) Evidence for generation of oxidative stress in brain by MPTP: in vitro and in vivo studies in mice. Brain Res 749:44-52.

Sriram K, Shankar SK, Boyd MR, Ravindranath V (1998) Thiol oxidation and loss of mitochondrial complex I precede excitatory amino acid mediated neurodegeneration. J Neurosci 18:10287-10296.

Streifler M, Cohn DF, Hirano A, Schujman E (1977) The central nervous system in a case of neurolathyrism. Neurology 27:1176-1178.

Sturtz LA, Diekert K, Jensen LT, Lill R, Cizewski Culotta V (2001) A fraction of yeast $\mathrm{Cu}-\mathrm{Zn}$ superoxide dismutase and its metallochaperone CCS localize to the intermembrane space of mitochondria, a physiological role of SOD1 in guarding against mitochondrial oxidative damage. J Biol Chem 276:38084-38089.

Tapia R, Medina-Ceja L, Pena F (1999) On the relationship between extracellular glutamate, hyperexcitation and neurodegeneration, in vivo. Neurochem Int 34:23-31.

Tietze F (1969) Enzymatic method for quantitative determination of nanofram amounts of total and oxidized glutathione; application to mammalian, blood and other tissues. Anal Biochem 287:502-522.

Vazquez EJ, Murphy T, Starke DW, Lassar A, Lesnefsky EJ, Mieyal JJ (2001) Does aging alter mitochondrial antioxidant enzyme contents in the heart? J Invest Med 49:285A.

Wells WW, Yang Y, Deitx TL, Gan ZR (1993) Thioltransferase. Adv Enzymol Relat Areas Mol Biol 66:149-201.

Xia XG, Harding T, Weller M, Bieneman A, Uney JB, Schulz JB (2001) Gene transfer of the JNK interacting protein-1 protects dopaminergic neurons in the MPTP model of Parkinson's disease. Proc Natl Acad Sci USA 98:10433-10438.

Zhou LZ, Johnson AP, Rando TA (2002) NFkB and AP-1 mediate transcriptional response to oxidative stress in skeletal muscle cells. Free Radic Biol Med 31:1405-1416. 